\title{
THYROID HYPOFUNCTION IN SPINAL CORD INJURY PATIENTS
}

\author{
By Ved Prakash, M.D., Max S. Lin, M.D., Chung H. Song, M.S. \\ and INDER PERKASH, M.D. \\ Spinal Cord Injury Service and the Department of Nuclear Medicine, \\ Veterans' Administration Hospital and Stanford University School of Medicine, \\ Palo Alto, California
}

\begin{abstract}
Our experience in the screening and detection of hypothyroidism in 225 spinal injury patients is described. Clinical features compatible with hypothyroidism are frequently encountered in these patients and require thyroid function testing to exclude or confirm thyroid hypofunction. Two cases of hypothyroidism, equivocal on clinical grounds alone, were first detected by a low value in screening tests for serum thyroxine levels and subsequently confirmed by a high serum TSH level. Low serum triiodiothyronine level is frequently found in apparently euthyroid patients with tetraplegia and is necessarily not an indicator of clinical hypothyroidism in these patients.
\end{abstract}

Key words: Thyroid hypofunction in spinal injury patients; Triiodothyronine.

\section{Introduction}

EARLY symptoms of hypothyroidism are usually non-specific and of insidious onset, and a high index of clinical suspicion is important in detecting this disorder. The detection may be particularly difficult in patients with spinal cord injury. The clinical symptomatology, consisting of apathy, sleepiness and constipation, suggesting hypothyroidism, could pass as a mental or physical consequence of the spinal trauma. In such patients, assessment of deep tendon reflexes does not help in diagnosing thyroid hypofunction. Under the circumstances, laboratory tests of thyroid function would appear to be of special importance. Claus-Walker (1972) reported that serum thyroxine $\left(\mathrm{T}_{4}\right)$ levels in acute tetraplegic patients tend to be significantly lower than those among chronic tetraplegics. Accordingly, we have routinely obtained simple thyroid function test results in our spinal injury patients to help interpret these test results for diagnosing hypothyroid in such patients. This paper presents test findings and our experience with the diagnosis of hypothyroidism in our patients.

\section{Methods and Materials}

A total of 225 spinal injury patients, 222 males and three females, were studied. Their age ranged from I 8-85 years, and averaged 40 years. The level of the spinal injury varied from $\mathrm{C}_{4}$ to $\mathrm{L}_{3}$ and was cervical in 107, thoracic in 95, and lumbar in 23 patients. The time interval between the spinal trauma and the laboratory testing of thyroid function was under 3 months in 55 patients and over 3 months in 170 patients.

Reprint request to: Ved Prakash, M.D., Department of Radiation Sciences, Loma Linda University, Loma Linda, California 92354, U.S.A. 
Serum triiodothyronine $\left(\mathrm{T}_{3}\right), \mathrm{T}_{4}$ and $\mathrm{TSH}$ were measured by radioimmunoassay (RIA) technique (Immuno- $\mathrm{T}_{3}, \mathrm{~T}_{4}$ and TSH Kit, Pantex, Santa Monica, California). $\quad T_{3}$ resin uptake T3-RU test was done using Pantex 'T3-uptake' kit. All patients were on a 2600 calorie diet containing $290 \mathrm{~g}$ carbohydrates. Venous blood was sampled after overnight fasting between 7 a.m. and 9 a.m. Twentyfive normal subjects and II 5 of the 225 spinal injury patients had all four tests. Each of the other IIO patients was first screened by $\mathrm{T}_{4}$ RIA and $\mathrm{T}_{3}-\mathrm{RU}$ tests. $\mathrm{TSH}$ levels and other measurements were obtained only when one or both of the screening tests were abnormal.

The II 5 patients on whom all four tests were performed were divided into five groups for analytical purposes.

Group I: Tetraplegics within 3 months post-injury (mean 56 days) referred to as 'acute tetraplegics' were also observing bedrest.

Group II: Tetraplegics over 3 months post-injury, when they were studied were referred as 'chronic tetraplegics', were ambulatory on wheelchair.

Group III: Paraplegics within 3 months post-injury (mean 55 days) were considered 'acute paraplegics' and were on bedrest.

Group IV: Paraplegics over 3 months post-injury considered as 'chronic paraplegics' were ambulating on wheelchair. paretics).

Group V: Ambulatory walking paretics (eight tetraparetics and seven para-

\section{Results}

Figures $\mathrm{I}-4$ show the results of all four tests obtained in each of the 25 normal subjects and II 5 patients. The mean plus/minus up to three to four standard deviations of the values obtained in the 25 normal subjects were considered to be within the normal range: $i . e .4 \cdot$ I to I I $4 \mu \mathrm{g} / \mathrm{dl}$ for $\mathrm{T}_{4}, 25$ to 36 per cent for $\mathrm{T}_{3}-\mathrm{RU}$, and 0 to $8 \mu \mathrm{uv} / \mathrm{ml}$ for TSH, and 63 to $\mathrm{I} 94 \mu \mathrm{g} / \mathrm{dl}$ for $\mathrm{T}_{3}$. These ranges were all essentially identical to the corresponding normal ranges suggested by manufacturers of the test kits used in this study.

All the II 5 patients had normal TSH levels (Fig. I). Although the mean TSH level among the acute paraplegics and that among the acute tetraplegics was slightly higher than the normal mean, these small differences were of doubtful significance $(0 \cdot \mathrm{I}<\mathrm{p}<0.2$, Fig. 4). On this basis, all I I 5 patients were considered to be euthyroid even though two of them had subnormal $\mathrm{T}_{4}$ levels (Fig. 2). The mean $\mathrm{T}_{4}$ level of each of the five groups of patients was not significantly different from the normal mean value (Fig. 2). Similarly, all except one paraplegic (Group IV) had $\mathrm{T}_{3}-\mathrm{RU}$ that appeared to be slightly higher than the normal mean (Fig. 3).

As shown in Figure 4, the $T_{3}$ level of the walking paretics was not significantly different from the normal value, but the paraplegics and especially the tetraplegics tended to have a low normal or subnormal $\mathrm{T}_{3}$ level. Mean serum $\mathrm{T}_{3}$ level of acute paraplegics was $100.3 \mathrm{ng} / \mathrm{dl}$ and that of chronic paraplegics was I I $4.3 \mathrm{ng} / \mathrm{dl}$; both of these were significantly lower than the mean serum $\mathrm{T}_{3}$ of the normal group ( $\mathrm{p}<0.005$ and $\mathrm{p}<0.02$ respectively). Similarly, chronic tetraplegics had a significantly lower $\mathrm{T}_{3}$ level of $92.6 \mathrm{ng} / \mathrm{dl}(\mathrm{p}<0.00 \mathrm{I})$. The lowest mean $\mathrm{T}_{3}$ levels were found among the eight acute tetraplegics. Their mean $\mathrm{T}_{3}$ level of $67.7 \mathrm{ng} / \mathrm{dl}$ was much lower than the normal group $(\mathrm{p} \ll 0.00 \mathrm{I})$. Of the eight patients, four had low normal ( 64 to $84 \mathrm{ng} / \mathrm{dl}$ ), and three had subnormal values (under $64 \mathrm{ung} / \mathrm{dl}$ ). Five of the 46 chronic tetraplegics had subnormal $\mathrm{T}_{3}$. All of the 


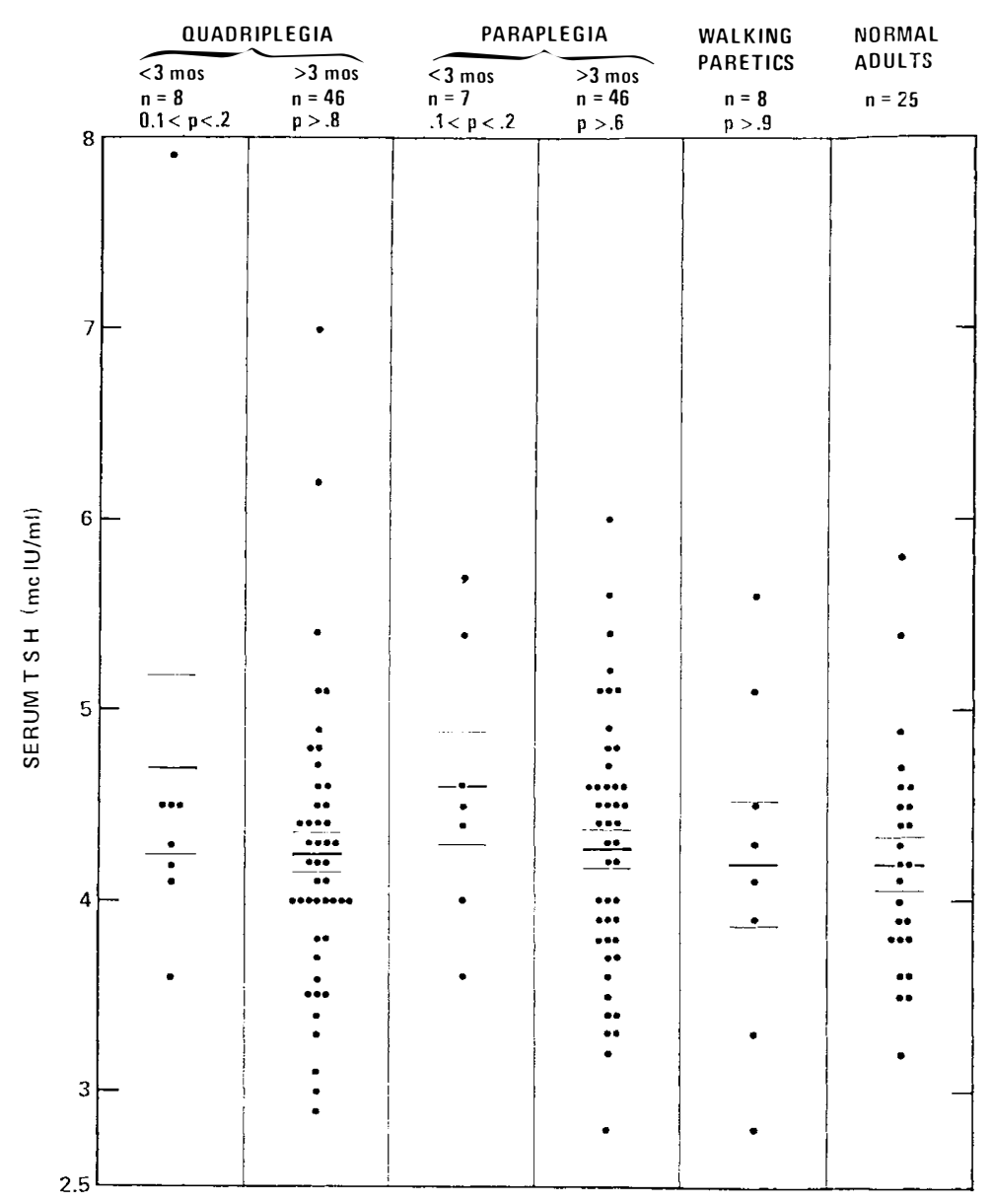

FIG. I

Serum thyroid stimulating hormone levels in normal adults, walking paretics, paraplegics and tetraplegics. The latter two groups of patients are each further subdivided into acute and chronic cases, according to whether the interval between the injury and the study is under or over 3 months. The number of subjects or patients in each of the six groups is indicated by ' $n$ '. The student ' $t$ ' testing for the significance of differences in means between a patient group and the normal adult group is shown in terms of $p$ values for each of the five patient groups. In the figure, each dot represents a subject, bold bar a group mean, and distance between a bold bar and an adjacent light bar the standard error of a mean.

three acute and the five chronic tetraplegics had normal $\mathrm{T}_{4}, \mathrm{~T}_{3}-\mathrm{RU}$, and $\mathrm{TSH}$, and all were considered to be clinically euthyroid.

Of the other IIO patients screened with $\mathrm{T}_{4}-\mathrm{RIA}$ and $\mathrm{T}_{3}-\mathrm{RU}$, none had a subnormal T3-RU. Only two had subnormal $\mathrm{T}_{4}$ levels of $\mathrm{I} \cdot 2$ and $2.5 \mu \mathrm{g} / \mathrm{dl}$, respectively. They also had low normal $\mathrm{T}_{3}-\mathrm{RU}$ ( 27 per cent) and grossly elevated TSH levels of 335 and II $7 \mu \mathrm{IU} / \mathrm{ml}$, respectively. Thus, they were considered hypothyroid. One of them had undergone radiation therapy for carcinoma of the esophagus and developed radiation myelopathy and possibly radiation thyroiditis 


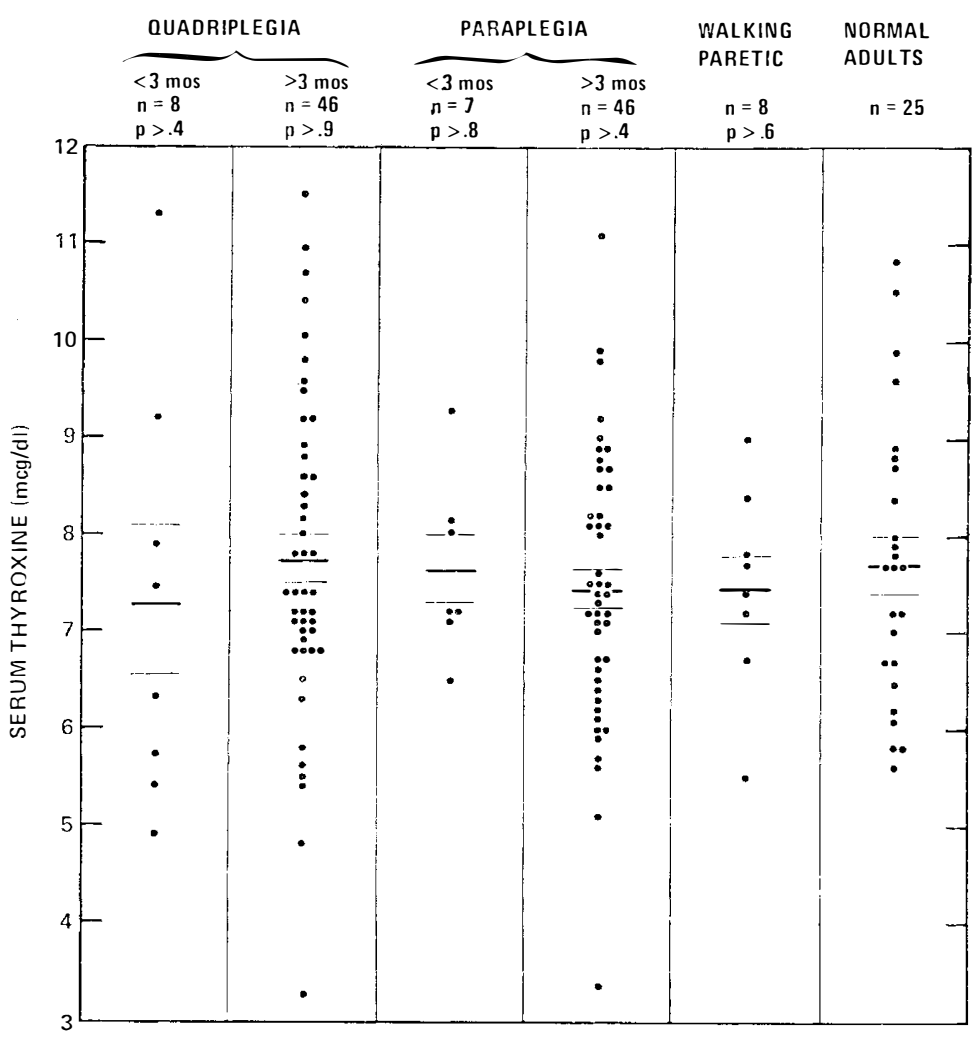

FIG. 2

Serum thyroxine levels in the six groups of subjects described in Figure I.

leading to hypothyroidism. The case histories of the other hypothyroid patient and that of one euthyroid patient who clinically appeared to be hypothyroid are illustrated.

Case No. I: 32-year-old $\mathrm{C}_{5}$ tetraplegic following a diving injury was admitted to Palo Alto V.A. Hospital about a year post-injury. He appeared to be apathetic and drowsy with slow speech. These symptoms were clinically thought to be due to depression. Physical examination revealed an obese tetraplegic male. There was no palpable goiter. The laboratory thyroid tests revealed a $\mathrm{T}_{4}$ level of $\mathrm{I} \cdot 2 \mu \mathrm{gm}$ per cent, $\mathrm{T}_{3}-\mathrm{RU}$ of $26 \cdot 8$ per cent and $\mathrm{TSH}$ of $335 \mu \mathrm{IU} / \mathrm{ml}$. His ${ }^{131} \mathrm{I}$ thyroid scan showed minimal patchy uptake in the gland, with a 24 -hour uptake of only 2 per cent. Antimicrosomal antibodies were raised to 4500 units $\mathrm{ml}$ (normal <25). Thus, he was felt to have an autoimmune thyroid disease as the cause of his hypothyroidism. His therapy was started with $50 \mu \mathrm{gm}$ of $\mathrm{T}_{3}$ and $\mathrm{T}_{4}$. After a few days, the $\mathrm{T}_{3}$ was discontinued and the $\mathrm{T}_{4}$ dose gradually increased to $\mathrm{I} 50 \mu \mathrm{gm} /$ day with a return of serum levels of both $\mathrm{T}_{4}$ and $\mathrm{TSH}$ to within normal limits. He showed a general improvement in well being.

Case No. 2: This 56-year-old man had an automobile accident and became $C_{5}$ tetraplegic and was transferred to Palo Alto V.A. Hospital 6 weeks post-injury. 


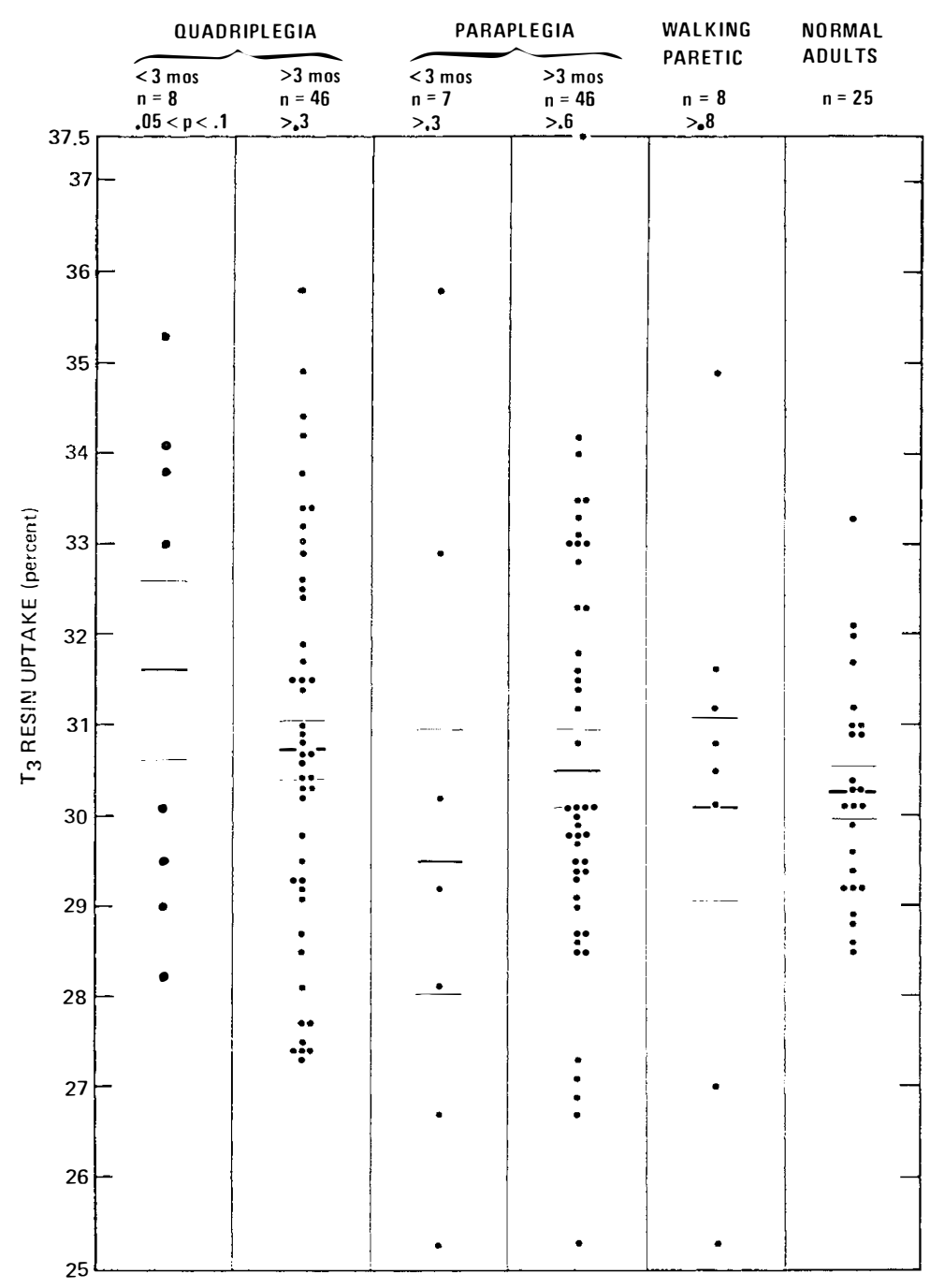

FIG. 3

$\mathrm{T}_{3}$ resin uptake values in the six groups of subjects described in Figure $\mathrm{I}$.

He appeared to be dull and lethargic with dry and atrophic skin. He was hypothermic $\left(96-98^{\circ} \mathrm{F}\right)$ and also had bradycardia (50-60/min). He was thought to have a clinical hypothyroidism. After drawing blood for thyroid function and other laboratory tests, he was started on $5 \mu \mathrm{g} \mathrm{T}_{3}$ per day. The tests revealed normal haemoglobin and electrolytes, Serum $\mathrm{T}_{4} 5.4 \mu \mathrm{g}$ per cent, $\mathrm{T}_{3}-\mathrm{RU} 29.5$ per cent, $\mathrm{T}_{3} 48 \mathrm{ng}$ per cent, $\mathrm{TSH} 4.5 \mu \mathrm{IU} / \mathrm{ml}$, and cholesterol $205 \mathrm{mg}$ per cent. The normal TSH level clearly showed absence of primary hypothyroidism. Since he had a head injury, the possibility of a secondary (pituitary) hypothyroidism was further evaluated by measuring serum levels of follicular stimulating hormone, lutenising hormone and growth hormone-they were all normal. Thus, he was felt to be euthyroid and the $T_{3}$ therapy was discontinued. 


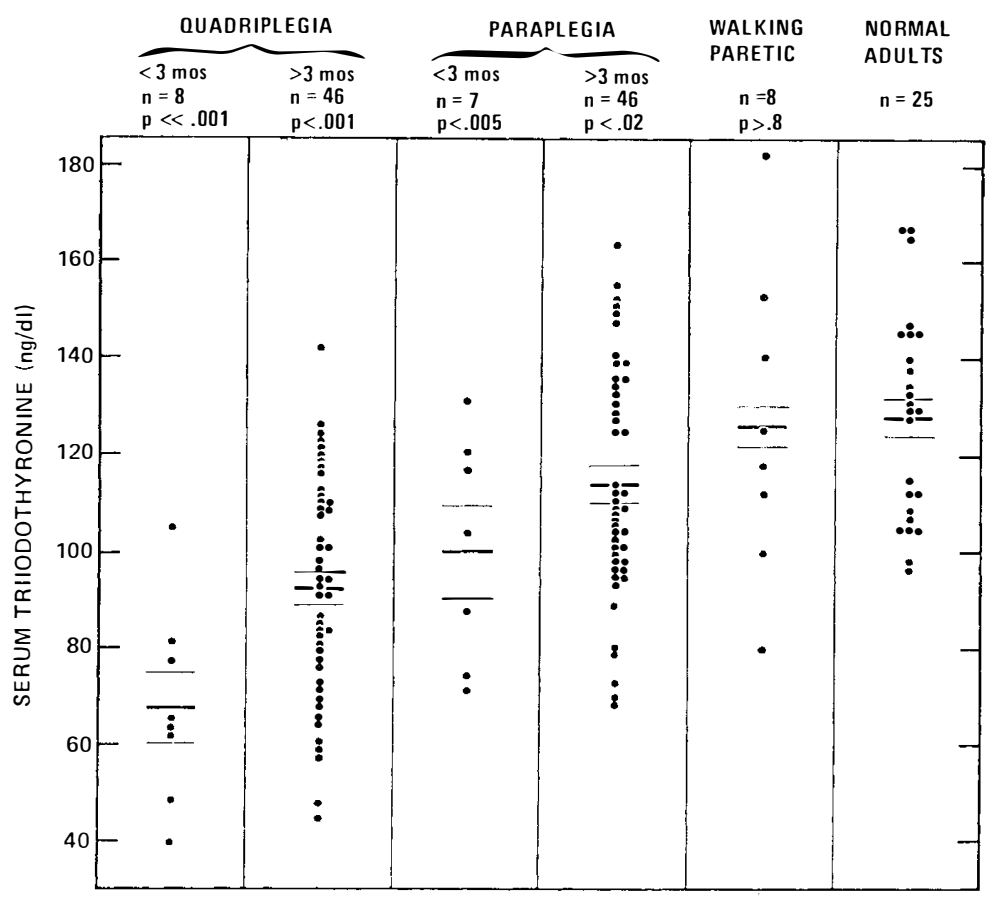

FIG. 4

Serum triiodothyronine levels in the six groups of subject described in Figure $\mathbf{I}$.

\section{Discussion}

In this study, the serum $\mathrm{T}_{4}$ level of spinal injury patients did not differ from that of normal controls. This observation does not corroborate the earlier findings of Claus-Walker (1977) who observed a decreased serum $\mathrm{T}_{4}$ in acute tetraplegic patients. Four of our patients had subnormal $\mathrm{T}_{4}$ levels. Two of these four also had abnormally high TSH levels and thus were hypothyroid. Clinically, both these patients did not appear to be hypothyroid, and the diagnosis could have been missed without the laboratory assessment of their thyroid function.

The two cases of hypothyroidism represent an incidence of 0.9 per cent of our 225 patients. As a proportion to total hospital admissions, the incidence of hypothyroidism has been reported to be 0.01 to 0.08 per cent by Mean (1948), and this figure could be an underestimate since mild cases of hypothyroidism are clinically not easily detectable and laboratory diagnosis of thyroid dysfunction has much advanced since then. A recent survey by Tunbridge (1975) shows a prevalence of hypothyroidism of 0.9 per cent in Wickham, north-east England. However, our series is small, and it is difficult to compare the incidence of hypothyroidism in our spinal injury patients with that of the general population.

A striking finding in our study is a low $\mathrm{T}_{3}$ level in many of our spinal injury patients who are euthyroid clinically and by other thyroid function tests. The depressed $\mathrm{T}_{3}$ level does not appear to indicate a thyroid hypofunction. This impression is further supported by others, where low $\mathrm{T}_{3}$ levels have been recorded in a variety of other non-thyroidal conditions. These conditions include fasting 
(Spaulding, 1976); disseminated malignancy (Carter, 1977); and many other acute and chronic illnesses (Burger, 1976).

Most endogenous $\mathrm{T}_{3}$ is produced by an extrathyroidal conversion of $\mathrm{T}_{4}$ to $\mathrm{T}_{3}$ (Cavalieri, I977). The low serum $\mathrm{T}_{3}$ level in spinal injury patients probably represents a diminished peripheral conversion of $\mathrm{T}_{4}$ to $\mathrm{T}_{3}$. Little is known about the control of $\mathrm{T}_{4}$ to $\mathrm{T}_{3}$ conversion. Our data suggest an association between serum $\mathrm{T}_{3}$ depression and physical inactivity; the $\mathrm{T}_{3}$ level is generally lower in tetraplegics than in paraplegics, the depression being greater in acute cases than in chronic cases, and the walking paretics have normal $\mathrm{T}_{3}$ levels. It is tempting to speculate that physical inactivity may bring about a diminished $\mathrm{T}_{4}$ to $\mathrm{T}_{3}$ conversion peripherally. Caloric restriction readily induces low serum $\mathrm{T}_{3}$ levels in normal individuals (Merrimec, 1976). Although all of our patients were on regular diet, decreased intake of calories in acutely ill patients may be contributing to low $\mathrm{T}_{3}$ levels.

T4-RIA and T3-RU tests are simple and require few hours to complete and appear to be suitable as primary screening tests in spinal cord injury patients with suspected hypothyroidism. If these tests are consistent with the diagnosis of hypothyroidism, the suspicion may then further be confirmed by TSH RIA, which is generally I-day procedure. Since almost all spinal cord injury patients with abnormally low $\mathrm{T}_{3}$ RIA were felt to be euthyroid, serum $\mathrm{T}_{3}$ estimation does not seem to be as useful as the above-mentioned tests.

\section{Summary}

Thyroid function tests were performed in 225 spinal cord injury patients. Serum $T_{4}$ level and $T_{3}$ resin uptake, but not serum $T_{3}$ level, were found to be useful as screening tests, for thyroid hypofunction. Suspicion of hypothyroidism based on $\mathrm{T}_{4}$ and $\mathrm{T}_{3}$ resin uptake test was confirmed by serum $\mathrm{TSH}$ level. Clinically unsuspected hypothyroidism was detected in two patients (0.9 per cent). Among the paraplegics and the tetraplegics tested, the serum $\mathrm{T}_{3}$ level tended to be in the low normal or subnormal range, even though they were clinically euthyroid and the other thyroid functions were normal. Subnormal serum $\mathrm{T}_{3}$ levels (under $64 \mu \mathrm{g} / \mathrm{dl}$ ) were found in three out of eight euthyroid acute tetraplegics tested.

\section{RÉSUMÉ}

La fonction thyröidienne a été testée chez 225 malades atteints de lesions medullaires. Le taux sérique de $T_{4}$ et le taux d'absorption sur résine de $T_{3}$ permettent de détecter l'hypofonctionnement thyröidien. Par contre le baux sérique de $T_{3}$ s'est avéré inutile. Le diagnostic d'hypofonctionnement thyröidien fut confirmé par le niveau plasmatique de T.S.H. Un hypothyröidinne insoupçonné fut trouvé chez 2 malades $(0.9 \%)$. Chez les paraplégiques et les tetraplégiques examinés, le niveau plasmatique de $\mathrm{T}_{3}$ était à la limite inférieure du taux normal, ou un peu au-dessous, même s'ils étaient euthyröidiens cliniquement, et les autres tests thyridöidiens étaint normaux. Nous avons trouvés des niveaux plasmatiques de $T_{3}$ subnormaux (inférieur à $64 \mathrm{ug} / \mathrm{dl}$ ) chez 3 des 8 tetraplégiques aigues euthyröidiens examinés.

\section{ZUSAMMENFASSUNG}

Schilddrüsen Funktionsteste wurden an 225 Patienten mit Rückenmarkverletzungen durchgeführt. Serum $\mathrm{T}_{4}$ und $\mathrm{T}_{3}$ 'resin' stand aufwärts jedoch kein Serum $\mathrm{T}_{3}$ stand, erwies sich von Nutzen beim 'Screening Test' für Schildrüsen 'Hypofunktion'. Verdacht von 'Hypothyroidism' begründed auf ' $\mathrm{T}_{4}$ und $\mathrm{T}_{3}$ Resin uptake' hat sich durch 'Serum TSH Level' bestätigt. Klinisch unverdächtiger 'Hypothyroidism' wurde in 2 patienten 
THYROID HYPOFUNCTION IN SPINAL CORD INJURY PATIENTS

entdeckt $(0.9 \%)$. Unter den Paraplegics und Tetraplegics untersucht, hatte das 'Serum T3 Level' die Tenden sich in der niederen-Normalen oder unter-Normalen Region zu halten, trotzdem sie kilinisch 'Euthyroid' waren und die anderen Schilddrüsen Funktionen normal waren. Unter normale 'Serum $\mathrm{T}_{3}$ Level' (unter $64 \mathrm{ug} / \mathrm{dl}$ ) wurden in 3 von 8 Euthyroid acuten Tetraplegics Patienten, welche getestet wurden, gefunden.

\section{REFERENCES}

Burger, A. Suter, P. \& Nicod, P. (1976). Reduced active thyroid hormone levels in acute illness. Lancet, $\mathbf{1}, 653-655$.

BURR, W. A., Griffiths, R. S. \& Black, E. (I975). Serum triiodothyronine and reverse triiodothyroinine concentration after surgical operation. Lancet, 2, I277-I279.

Carter, J. N., Corcoran, J. M. \& Eastman, C. J. (I974). Effect of severe chronic illness on thyroid function. Lancet, 27, 97 I-974.

CAVAlieri, R. P. \& RAPOPORT, B. (I977). Impaired peripheral conversion of thyroxine to triiodothyronine. Ann. Rev. Med., 28, 57-65.

Chopra, I. J., Solomon, D. H. \& ChOpra, V. (1974). Alterations in circulating thyroid hormones and thyrotropin in hepatic cirrhosis; evidence for euthyroidism despite subnormal serum T3. F. Clin. Endocrinol. Metab., 39, 50 I-5I I.

Claus-Walker, J., Campos, R. J. \& Carter, R. E. (I972). Calcium excretion in quadriplegics. Arch. of Phys. Med. Rehab, 53, I4-20.

Claus-Walker, J., Scurry, M., Carter, R. E. \& Campos, R. J. (1977). Steady state hormonal secretion in traumatic quadriplegia. F. Clin. Endocrinol. Metab., 44, 530-535.

Mean, J. H. (1948). The Thyroid and its Diseases, Second Edition, p. 205. J. B. Lippincott Company, Philadelphia, Penn.

MerimeE, T. J. \& FineberG, E. S. (1976). Starvation-induced alterations of circulating thyroid hormone concentration in man. Metabolism, 25, 79-83.

Spaulding, S. W., Chopra, I. J. \& SHERwin, R. S. (I976). Effect of caloric restriction and dietry composition on serum $\mathrm{T}_{3}$ and reverse $\mathrm{T}_{3}$ in man. $\mathcal{F}$. Clin. Endocrinol. Metab., 42, 197-200.

Turnbridge, W. M. G. \& Evered, D. (1975). The prevalence of thyroid disorders in an English community (Abstract). Proceedings-7th International Thyroid Conference, Boston, Mass. 